\title{
In Memoriam: Roger Yates Anderson (1927-2021)
}

\author{
Kirsten Menking
}

Received: 12 May 2021/Accepted: 26 May 2021/Published online: 4 June 2021

(C) The Author(s), under exclusive licence to Springer Nature B.V. 2021

Roger Yates Anderson (Fig. 1), Professor Emeritus in the Department of Earth and Planetary Sciences at the University of New Mexico, Albuquerque, passed away from COVID-19 on 9 January 2021 in Poughkeepsie, New York (USA), where he lived with me, his life partner of the last 24 years, and our adopted son, Blake. Like Herb Wright and Dan Livingstone, Roger was a pioneer in paleolimnology. His interest in lakes began during his childhood in a Chicago suburb and involved swimming, canoeing, and fishing in waterbodies large and small, throughout the upper Midwest. After suffering a brain hemorrhage at age 11, he struggled in school, eventually dropping out at age 17 and joining the Navy toward the end of World War II. After discharge, he attended Beloit College, Wisconsin, for 2 years, where he met his wife, Lucille Hubbell. Not sure what he wanted to study, Roger took a leave of absence and worked in his father's print shop while starting a family, but soon grew restless and returned to school, this time at the University of Arizona, Tucson, where he fell in love with Geology and completed additional coursework in Botany and Zoology. His broad knowledge of all three subjects would prove extremely useful in the future as he

K. Menking ( $\square)$

Department of Earth Science and Geography, Vassar

College, Poughkeepsie, NY 12603, USA

e-mail: kimenking@vassar.edu worked to uncover Earth's history of climate change, as recorded in lake sediments.

After earning his bachelor's degree, Roger moved on to graduate studies at Stanford University, California, where he was in residence for less than a year before being hired as an Assistant Professor at the University of New Mexico, Albuquerque. He finished his dissertation, on pollen extracted from rocks that spanned the Cretaceous-Tertiary boundary, while beginning his teaching career. In carrying out his $\mathrm{PhD}$ research, Roger discovered 39 new fossil species and eight new genera (Anderson 1960), starting a lifelong fascination with micropaleontology that would dovetail with his research in sedimentology and stratigraphy.

Following his doctoral work, Roger and graduate student Douglas Kirkland embarked on a study of the Todilto Formation, a Jurassic varve sequence in northwestern New Mexico (Anderson and Kirkland 1960). At the time, the origin of non-glacial varved sediments was controversial (Anderson 1961, 1996), with some scientists skeptical that the layers represented annual sedimentation, but Roger and Doug sent thickness measurements to renowned dendrochronologists Andrew Ellicott Douglass and Bryant Bannister at the University of Arizona, who used a precursor technique to today's spectral analysis to reveal that the thickness of Todilto varves contained periods very similar to the 11-year sunspot cycle. This finding, 


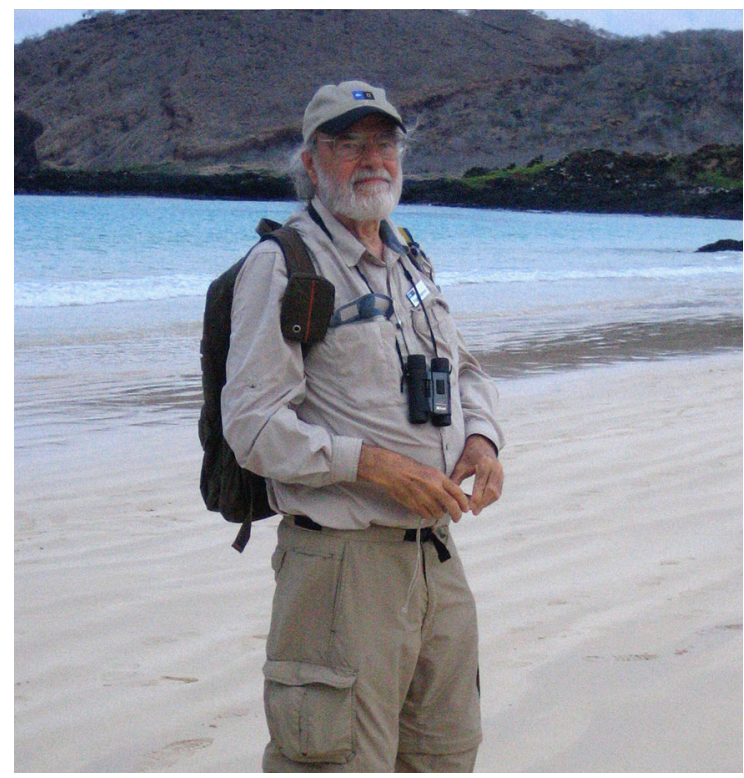

Fig. 1 Roger on a fieldtrip to the Galapagos at age 80. (Photo by Kirsten Menking)

along with the fact that the varves could be correlated across different outcrops located several $\mathrm{km}$ apart (Anderson and Kirkland 1966), and the presence of thin organic-rich laminae produced by phytoplankton blooms (Anderson and Koopmans 1963; Anderson 1964), strongly suggested that the layers were caused by a seasonal/annual cycle.

Always an early adopter of technological innovations, Roger partnered with mathematician Lambert Koopmans to use the newly developed BlackmanTukey method of spectral analysis to re-analyze the Todilto and several other laminated sequences (Anderson 1961; Anderson and Koopmans 1963), one of the first uses of a computer for that purpose. That study suggested 22-, 86-, and 180-year oscillations in the Todilto that led Roger to realize that longer varve sequences might be able to confirm additional solar climate periods, for which meteorological records were too short to show more than one or two full cycles. Permian limestones and evaporites from the Delaware Basin of southeastern New Mexico and western Texas (Bell Canyon, Castile, and Salado Formations) contained exactly what he was looking for, a sequence of approximately 260,000 annual laminations that would become the focus of new graduate student Walter Dean's dissertation research, and ongoing collaborations with Doug Kirkland.
Together, the team acquired multiple cores throughout the basin and pioneered the use of sliding correlation coefficients, calculated by a computer, to show that the same laminae could be recognized over distances as great as $100 \mathrm{~km}$ (Anderson et al. 1972; Dean and Anderson 1974). Measuring the thickness of the individual varves and compiling them into a time series took many years, but in the end, the data were entered into a voluminous set of IBM punch cards for spectral analysis, which revealed orbital eccentricity and precession cycles along with 2000-3000and $\sim 200$-year periods (Anderson 1982a).

Although Roger would go on to other projects, he returned to the Castile evaporite sequence repeatedly, as new analytical techniques became available. Well into his $80 \mathrm{~s}$, he used wavelet analysis to interrogate the sequence anew, finding, among other things, that the 2000-3000-year period he had previously identified actually consisted of two separate periods of 2300 and 1500 years that appeared at different times throughout the record (Anderson 2011). At the time of his death at age 93, he was working on yet another manuscript to explain what he called this "quasi bi-millennial oscillation" or QBMO, which he noted was present not only during the Permian, but is also found in the late Pleistocene and Holocene, a testament to the remarkable stability of solar forcing.

Roger's interests in the Castile were not limited to its climate record, but also branched into structural geology (Kirkland and Anderson [1970] discusses the nature and origins of microfolds within the sequence), the sedimentology of evaporite deposits and what that reveals about their formation (e.g. sabkha versus deep water; Dean et al. 1975; Dean and Anderson 1978; Anderson and Dean 1995), and the origin of dissolution and collapse breccias (Anderson et al. 1978; Anderson and Kirkland 1980). The latter work involved the use of a simple physical analog of groundwater flow in a fractured salt deposit and demonstrated that the density differences between inflowing freshwater and the brine that resulted from salt dissolution could produce downward drainage of the salty water, thereby exposing the evaporites to further attack by fresher waters. These findings led Roger to urge caution as the U.S. Department of Energy began investigating the Castile as a site for the Waste Isolation Pilot Plant, a geologic repository for high-level radioactive waste (Anderson 1981, 1982b; Spiegel and Anderson 1988). 
At the same time that Roger was adopting new mathematical and computer techniques for analyzing geologic time series, he recognized the need to better understand the mechanisms of varve formation through modern studies of the process (Anderson 1977; Anderson and Dean 1988). Though he was not the first person to use sediment traps to capture the rain of particles throughout the water column, he was responsible for important innovations that greatly enhanced the information gathered from such studies. First, he devised a cylindrical trap with baffles at the mouth and a funnel at the base that amplified the background sedimentation rate, making depositional events easier to distinguish from one another (Fig. 2). Second, he invented and patented a device he called an "intervalometer" that dispensed a layer of Teflon powder into the trap at user-specified time intervals (Anderson 1977). This time stamping allowed him to determine precisely when clastic sediments were mobilized by storms or spring snowmelt pulses and when specific phytoplankton bloomed. Roger took on a new graduate student, Edward Nuhfer, to construct and field test the equipment in a variety of lakes and reservoirs, work that led to discoveries about the power of seasonal overturns to remobilize and redistribute sediment and to deduce how the chemistry and mineralogy of seston changed during each season (Nuhfer and Anderson 1985).

With Ed and Walter Dean, Roger deployed additional traps and intervalometers into several lakes in Washington State around the time of the Mt. St. Helens eruption (Anderson et al. 1984, 1985). A trap

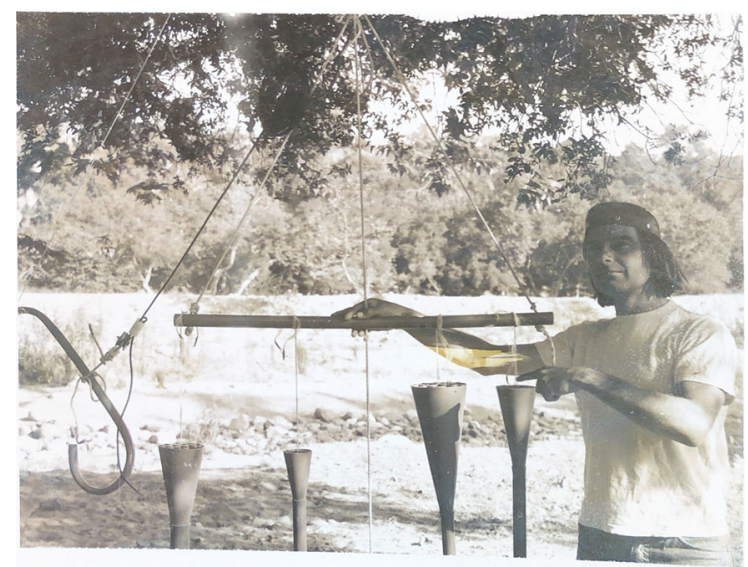

Fig. 2 Roger circa 1971 working on his sediment trap design. (Photo by Lucille Hubbell) deployed in Spirit Lake was obliterated by the unexpected lateral blast, as was the colorful Harry Truman, owner of the Spirit Lake Lodge, who Roger remembered stamping his foot on the ground and yelling at the mountain each time it was rocked by an earthquake that presaged the coming event. The team's work at Coldwater Lake (Anderson et al. 1985), in the blast zone, demonstrated distinct seasonal sedimentation patterns associated with spring snowmelt followed by summer dry periods, and suggested an analog for lacustrine records from Precambrian and early Paleozoic landscapes, which lacked vegetative cover. A combination of sediment trap and coring studies at Williams Lake, in eastern Washington, showed that the Mt. St. Helens ash blanket sank, broke into pieces, and then foundered in the lake bottom sediments, ultimately displacing those sediments upward and settling tens of centimeters below the sediment water interface (Anderson et al. 1984). This finding has implications for tephrochronology inasmuch as tephra layers may be younger than the lacustrine sediments in which they are found embedded.

As Roger's sediment trap work became known, other scientists reached out to him for help with their studies, leading him to create a side business known as the Aquatic Monitoring Institute, which he operated out of a machine shop at his home in Albuquerque. His traps and intervalometers were deployed in a number of lakes throughout the U.S., in the Arctic and Antarctica, and in the Pacific Ocean, off of the California coast. The latter studies, carried out with colleagues Eileen Hemphill-Haley, Jim Gardner, Walter Dean, and Roger's then graduate student Braddock Linsley, demonstrated that laminated oceanic sediments found along the California margin were in fact varves, that they contained a detailed record of ENSO throughout the late Pleistocene and Holocene, and that variability in the strength of El Niño and La Niña events appeared tied to solar forcing (Anderson et al. 1987, 1990; Dean et al. 1994). Even as the rest of the paleoclimate community was concerning itself with documenting the role of Milankovitch cycles in Pleistocene climate change, Roger continued to emphasize the importance of solar variability through his detailed work with annually laminated sediments (Anderson 1991, 1992).

During the late 1980s, Roger also made important contributions to our understanding of atmospheric 
hydrologic processes. He and a group of students and colleagues drilled into the lake beds of late Pleistocene Lake Mojave, the terminus of the Mojave River in hyper-arid eastern California, and to their surprise, the group identified evidence for Holocene lakes. These water bodies are indicative of clusters of extreme moisture-rich storms that hit the river's headwaters in the San Bernardino Mountains, resulting in floods that were so massive that they overcame the large transmission losses along the river and created the lakes (Enzel et al. 1989, 1992). The North Pacific storms identified by the team became known later as the "pineapple express," and are now recognized as atmospheric rivers, though at the time Roger and the team were working, gridded data of atmospheric moisture were not yet sufficiently common to enable these phenomena to be studied further. Still, the team's efforts well explained the paleohydrology of the late Pleistocene and Holocene lake stands (Wells et al. 2003).

Along with his central role in our understanding of varve formation and the paleoclimate information embedded therein, another important contribution Roger made to paleolimnology and paleoceanography was his early adoption of a multi-proxy approach in lake studies, born of his broad undergraduate training in natural history. With Doug Kirkland, he led an ambitious study of the Pleistocene Rita Blanca formation in the Texas Panhandle, bringing together scientists to analyze the pollen, ostracodes, insects, fish, and plant macrofossils of the sediments, in addition to their mineralogy, grain size, chemistry, and isotopic composition (Anderson and Kirkland 1969). This study became a model for future work carried out by his graduate student Platt Bradbury on Zuni Salt Lake in New Mexico, and by Roger, Platt, and Walter Dean on Elk Lake in Minnesota [see Bradbury and Dean (1993) and Roger's chapters therein; Dean et al. 1984)], and later by graduate student Bruce Allen on Pleistocene pluvial Lake Estancia in central New Mexico (Allen and Anderson 1993, 2000).

My own involvement with Roger began as a postdoc, when I worked primarily with him, Bruce, and hydrologists Nabil Shafike and Kamran Syed on a numerical modeling project aimed at determining what climate conditions were necessary to raise Lake Estancia to its late Pleistocene highstands. The work again reflected Roger's deep creativity and holistic approach to every scientific question, inasmuch as he had written the proposal to bring together modern meteorological and hydrogeological observations with models of groundwater flow, surface runoff, and lake energy balance for comparison to ostracode-dated shorelines and basin-center stratigraphy (Menking et al. 2000, 2003, 2004). Through the various papers we wrote together over the past two decades, he imparted that holistic view, and additionally, taught me how to use all of the tools in his machine shop for the construction of scientific equipment and how to identify pollen. The latter assistance proved very helpful to my teaching of a project-based Paleoclimatology senior seminar at Vassar College. Well into his late 80 s, he continued to publish papers with me on Lake Estancia and on the climate history of New York's Hudson River Valley (Menking et al. 2012, 2018).

Roger was a brilliant scientist, teacher, and mentor to many students who got their start working with him. This short summary of his work, however, captures only part of who he was. Those who are interested in learning more about his personal life and his deep commitment to peace and social justice are welcome to read a companion biography at https://tinyurl.com/ rogermem. In addition to me and our adopted son, he is survived by seven other children, 12 grandchildren, and 12 great-grandchildren.

Acknowledgements I would like to thank Yehouda Enzel, Brad Linsley, and Ed Nuhfer for their helpful contributions to the manuscript.

\section{References}

Allen BD, Anderson RY (1993) Evidence from western North America for rapid shifts in climate during the last glacial maximum. Science 260:1920-1923

Allen BD, Anderson RY (2000) A continuous, high-resolution record of late Pleistocene climate variability from the Estancia basin, New Mexico. Geol Soc Am Bull 112:1444-1458

Anderson RY (1960) Cretaceous-tertiary palynology, Eastern Side of the San Juan Basin, New Mexico. State Bureau of Mines and Mineral Resources New Mexico Institute of Mining and Technology Memoir 6

Anderson RY (1961) Solar-terrestrial climatic patterns in varved sediments. Ann NY Acad Sci 95:424-439

Anderson RY (1964) Varve cycle of stratification. In: Merriam DF (ed) Symposium on cyclic sedimentation. Kansas Geol Survey Bull, vol 169, pp 1-20 
Anderson RY (1977) Short term sedimentation response in lakes in western United States as measured by automated sampling. Limnol Oceanogr 22:423-433

Anderson RY (1981) Deep-seated salt dissolution in the Delaware basin, Texas and New Mexico. New Mexico Geol Soc Special Publ 10:133-145

Anderson RY (1982a) A long geoclimatic record from the Permian. J Geophys Res 87:7285-7294

Anderson RY (1982) Deformation-dissolution potential of bedded salt, waste isolation pilot plant site, Delaware Basin, New Mexico. In: Lutze W (ed) Scientific basis for radioactive waste management-V. Elsevier Science Publishing, New York, pp 449-458

Anderson RY (1991) Solar variability captured in climatic and high-resolution paleoclimatic records: a geological perspective. In: Sonett CP, Giampapa MS, Matthews MS (eds) The sun in time. University of Arizona Press, Tucson, pp 543-561

Anderson RY (1992) Possible connection between surface winds, solar activity and the Earth's magnetic field. Nature 358:51-53

Anderson RY (1996) Seasonal sedimentation: a framework for reconstructing climatic and environmental change. Geol Soc Spec Publ 116:1-15

Anderson RY (2011) Enhanced climate variability in the tropics: A $200000 \mathrm{yr}$ annual record of monsoon variability from Pangea's equator. Clim past 7:757-770

Anderson RY, Dean WE (1988) Lacustrine varve formation through time. Palaeogeog Palaeoclimat Palaeoecol 62:215-235

Anderson RY, Dean WE (1995) Filling the Delaware Basin: hydrological and climatic controls on the Upper Permian Castile Formation Varved Evaporite. In: Scholle PA, Peryt TM, Ulmer-Scholle DS (eds) The Permian of Northern Pangea. Springer, Berlin, pp 61-78

Anderson RY, Kirkland DW (1960) Origin, varves, and cycles of Jurassic Todilto formation, New Mexico. AAPG Bull 44:37-52

Anderson RY, Kirkland DW (1966) Intrabasin varve calibration. Geol Soc Am Bull 77:241-256

Anderson RY, Kirkland DW (1969) Paleoecology of an early Pleistocene lake on the High Plains of Texas, vol 113. Geological Society of America, New York

Anderson RY, Kirkland DW (1980) Dissolution of salt deposits by brine density flow. Geology 8:66-69

Anderson RY, Koopmans LH (1963) Harmonic analysis of varve time series. J Geophys Res 68:877-893

Anderson RY, Hemphill-Haley E, Gardner JV (1987) Persistent late Pleistocene-Holocene seasonal upwelling and varves off the coast of California. Quat Res 28:307-313

Anderson RY, Kietzke KK, Rhodes DJ (1978) Development of dissolution breccias, northern Delaware Basin, New Mexico and Texas. In: Austin GS (ed) Geology and mineral deposits of Ochoan Rocks in Delaware Basin and Adjacent Areas. New Mexico Bureau of Mines and Mineral Resources Circular, vol 159, pp 47-52.https://www.wipp. energy.gov/information_repository/cca/cca_1996_ references/Chapter\%202/CREL243.PDF

Anderson RY, Linsley BK, Gardner JV (1990) Expression of seasonal and ENSO forcing in climatic variability at lower than ENSO frequencies: evidence from Pleistocene marine varves off California. Palaeogeog Palaeoclimat Palaeoecol 78:287-300

Anderson RY, Nuhfer EB, Dean WE (1984) Sinking of volcanic ash in uncompacted sediment in Williams Lake, Washington. Science 225:505-508

Anderson RY, Nuhfer EB, Dean WE (1985) Sedimentation in a blast-zone lake at Mount St. Helens, Washington-implications for varve formation. Geology 13:348-352

Anderson RY, Dean WE, Kirkland DW, Snider HI (1972) Permian Castile varved evaporite sequence, west Texas and New Mexico. Geol Soc Am Bull 83:59-86

Bradbury JP, Dean WE (1993) Elk Lake, Minnesota: evidence for rapid climate change in the north-central United States. Geological Society-America, Boulder, Colorado, USA, Special Paper 276, pp 1-336

Dean WE, Anderson RY (1974) Application of some correlation coefficient techniques to time-series analysis. Math Geol $6: 363-372$

Dean WE, Anderson RY (1978) Salinity cycles: Evidence for subaqueous deposition of Castile Formation and lower part of Salad Formation, Delaware Basin, Texas and New Mexico. In: Austin GS (ed) Geology and mineral deposits of Ochoan Rocks in Delaware Basin and Adjacent Areas. New Mexico Bureau of Mines and Mineral Resources Circular, vol 159, pp 15-20

Dean WE, Davies GR, Anderson RY (1975) Sedimentological significance of nodular and laminated anhydrite. Geology 3:367-372

Dean WE, Gardner JV, Anderson RY (1994) Geochemical evidence for enhanced preservation of organic matter in the oxygen minimum zone of the continental margin of northern California during the Late Pleistocene. Paleoceanography 9:47-61

Dean WE, Bradbury RY, Anderson RY, Barnosky CW (1984) The variability of Holocene climate change: evidence from varved lake sediments. Science 226:1191-1194

Enzel Y, Cayan DR, Anderson RY, Wells SG (1989) Atmospheric circulation during Holocene lake stands in the Mojave Desert: evidence of regional climate change. Nature 341:44-47

Enzel Y, Brown WJ, Anderson RY, McFadden LD, Wells SG (1992) Short-duration Holocene lakes in the Mojave River drainage basin, southern California. Quat Res 38:60-73

Kirkland DW, Anderson RY (1970) Microfolding in the Castile and Todilto evaporites, Texas and New Mexico. Geol Soc Am Bull 81:3259-3282

Menking KM, Peteet DM, Anderson RY (2012) Late-glacial and Holocene vegetation and climate variability, including major droughts, in the Sky Lakes region of southeastern New York State. Palaeogeog Palaeoclimat Palaeoecol 353-355:45-59

Menking KM, Polyak VJ, Anderson RY, Asmerom Y (2018) Climate history of the southwestern United States based on Estancia Basin hydrologic variability from 69 to $10 \mathrm{ka}$. Quat Sci Rev 200:237-252

Menking KM, Anderson RY, Shafike NG, Syed KH, Allen BD (2004) Wetter or colder during the Last Glacial Maximum? Revisiting the pluvial lake question in southwestern North America. Quat Res 62:280-288

Menking KM, Syed KH, Anderson RY, Shafike NG, Arnold JG (2003) Model estimates of runoff in the closed, semiarid 
Estancia basin, central New Mexico, USA. Hydrolog Sci J 48:953-970

Menking KM, Anderson RY, Brunsell NA, Allen BD, Ellwein AL, Loveland TA, Hostetler SW (2000) Evaporation from groundwater discharge playas, Estancia Basin, central New Mexico. Global Planet Change 25:133-147

Nuhfer EB, Anderson RY (1985) Changes in sediment composition during seasonal resuspension in small shallow dimictic inland lakes. Sediment Geol 41:131-158

Spiegel Z, Anderson RY (1988) WIPP or is "how wet" the real question? Eos 69(625):628
Wells SG, Brown WJ, Enzel Y, Anderson RY, McFadden LD (2003) Late Quaternary geology and paleohydrology of pluvial Lake Mojave, southern California. In: Enzel Y, Wells SG, and Lancaster N (eds) Paleoenvironments and Paleohydrology of the Mojave and Southern Great Basin Deserts. Geological Society-America, Boulder, Colorado, USA, Special Paper 368, pp 79-114

Publisher's Note Springer Nature remains neutral with regard to jurisdictional claims in published maps and institutional affiliations. 